\title{
Author Correction: Targeted scavenging of extracellular ROS relieves suppressive immunogenic cell death
}

\author{
Hongzhang Deng, Weijing Yang, Zijian Zhou, Rui Tian, Lisen Lin, Ying Ma, Jibin Song (1) \& Xiaoyuan Chen (1)
}

Correction to: Nature Communications https://doi.org/10.1038/s41467-020-18745-6, published online 02 October 2020.

This Article contained an error in both the legend to Fig. 3 and the description of Fig. $3 \mathrm{k}$ in the Results section. The Fig. 31 legend incorrectly stated that the quantitative analysis was based on $n=5$ independent replicates, this should have stated $n=3$ independent replicates. In addition, the sentence in the Results section entitled 'Investigation of PEG-TECM-NS/OLE-induced ICD and in vitro anticancer efficacy' the following sentence 'As shown in Fig. 3k, l, the percentage of late apoptotic cells (Annexin V-FITC and 7-AAD double stained) was $36.6 \%$ when treated with PEG-TECM-NS/OLE pretreated with pH 6.8.' incorrectly stated that the percentage of late apoptotic cells was 36.6\%; this sentence now reads 'As shown in Fig. 3k, l, the percentage of late apoptotic cells (Annexin V-FITC and 7-AAD double stained) was $24.7 \%$ when treated with PEG-TECM-NS/OLE pretreated with $\mathrm{pH}$ 6.8.' The pdf and HTML versions of the Article have been updated.

Published online: 01 July 2021

\footnotetext{
(c) (1)

Open Access This article is licensed under a Creative Commons Attribution 4.0 International License, which permits use, sharing, adaptation, distribution and reproduction in any medium or format, as long as you give appropriate credit to the original author(s) and the source, provide a link to the Creative Commons license, and indicate if changes were made. The images or other third party material in this article are included in the article's Creative Commons license, unless indicated otherwise in a credit line to the material. If material is not included in the article's Creative Commons license and your intended use is not permitted by statutory regulation or exceeds the permitted use, you will need to obtain permission directly from the copyright holder. To view a copy of this license, visit http://creativecommons.org/licenses/by/4.0/.
}

(c) The Author(s) 2021 